\title{
Hubungan Pekerjaan Ibu Dengan Kejadian Persalinan Preterm Dengan Ketuban Pecah Dini di RSUD Dr. Rasidin Padang dan RSIA Siti Rahmah
}

\author{
Gladeva Yugi Antari ${ }^{1)}$, Baiq Ricca Afrida ${ }^{1)}$ \\ Email: gladevaantari@yahoo.com \\ ${ }^{1)}$ STIKES YARSI MATARAM, PRODI KEBIDANAN JENJANG D.III
}

\begin{abstract}
ABSTRAK
Latar Belakang, persalinan preterm dapat meningkatkan angka kematian bayi secara signifikan, dimana tingkat kejadian persalinan preterm berkisar 5\% sampai $18 \%$ dari seluruh persalinan. Berdasarkan data WHO tahun 2013, Indonesia menempati peringkat ke 5 dari 10 negara yang memiliki jumlah persalinan preterm tertinggi di dunia sebesar 675.700 kelahiran preterm. Persalinan preterm disebabkan oleh karena banyak faktor, 50\% terjadi secara spontan, yang terbagi menjadi $30 \%$ akibat ketuban pecah dini (KPD) dan sisanya 20\% dilahirkan atas indikasi ibu/janin. Banyak faktor yang dapat meningkatkan kemungkinan persalinan preterm, sebagian bersifat genetik, infeksi, nutrisi, perilaku dan lingkungan. Namun dalam banyak kasus persalinan preterm, munculnya pemicu persalinan yang dini terjadi secara subklinis. Salah satu faktor adalah pekerjaan. Tujuan penelitian ini adalah mengetahui hubungan pekerjaan ibu dengan persalinan preterm dengan ketuban pecah dini. Desain penelitian cross sectional comparative, penelitian dilakukan di RSUD Dr. Rasidin Padang dan RSIA Siti Rahmah pada bulan September 2015-Juli 2016. Sampel penelitian ini adalah ibu bersalin pretem sebanyak 40 orang yang dipilih secara consecutive sampling, sampel dibagi menjadi 2 kelompok yaitu ibu bersalin preterm dengan ketuban pecah (KPD) dan ibu bersalin preterm tidak ketuban pecah dini (tidak KPD). Secara statistik terdapat tidak terdapat hubungan bermakna pekerjaan ibu dengan persalinan preterm KPD dan pretem tidak KPD. Kesimpulan penelitian ini bahwa nilai $\mathrm{p}=1$ diperoleh nilai $\mathrm{p}>0,05$ maka dapat disimpulkan bahwa tidak terdapat hubungan bermakna pekerjaan ibu antara persalinan preterm KPD dan tidak KPD.
\end{abstract}

Kata kunci: Pekerjaan, Persalinan Preterm.

\begin{abstract}
Background, preterm labor increases infant mortality significantly, where the incidence of preterm delivery ranges from 5\% to $18 \%$ of all deliveries. The WHO present 2013, Indonesia was ranked fifth out of 10 countries with the highest number of preterm birth in the world with amounted to 675.700 preterm births. Preterm labor caused by many factors, 50\% occurred spontaneously, divided into 30\% due to premature rupture of membranes (PROM) and $20 \%$ were born on indications of maternal/fetal. Factors of preterm labor increase in condition such as genetic, infection, nutrition, behavior and the environment. But in many cases of preterm labor, the emergence of early labor triggers occurs subclinically such as a work.The purpose of this study was the association between mother works with preterm labor with premature rupture of membranes. The study design was comparative crosssectional at Dr. Rasidin Padang hospital and Siti Rahmah hospital in September to July 2016. Samples in this study are 40 inpartu preterm were selected by consecutive sampling, samples were divided with preterm inpartu with preterm rupture of membranes and preterm inpartu without premature rupture of membranes. this study show is no significant association between the work of mothers with preterm delivery of SPD and preterm not KPD. The conclusion of this study that the value of $p=1$ obtained a value of $p>0.05$, it can be concluded that there is no significant relationship between maternal work between preterm KPD delivery and not KPD.
\end{abstract}

Keywords: a Work, Preterm Labor. 


\section{A. LATAR BELAKANG}

Angka angka kematian bayi (AKB) pada saat ini masih menjadi persoalan di Indonesia. Menurut World Health Organization (WHO) ditingkat dunia AKB berkisar sekitar 37 per 1000 kelahiran hidup[1]. Di Indonesia, lima tahun terakhir 2010, 2011, 2012 dan 2013 angka kematian ini tidak mengalami penurunan, berturut-turut sebesar 27, 26, 25 dan 24 per 1000 kelahiran hidup. Pada tahun 2014 angka ini tidak mengalami penurunan, masih tetap sama sebesar 24 per 1000 kelahiran hidup. Hal ini berarti dari setiap 1000 kelahiran hidup terdapat sekitar 24 bayi yang meninggal sebelum mencapai usia satu tahun[2]. Menurut data Badan Pusat Statistik (BPS) tahun 2012, jumlah AKB Sumatera Barat sebesar 27 per 1000 kelahiran hidup[3] dan di Kota Padang pada tahun 2014 angka kematian bayi terdapat sebesar 60 bayi[4].

Angka kematian bayi yang tinggi disebabkan oleh banyak faktor, penyebab utama kematian bayi di dunia adalah persalinan preterm dan berat lahir rendah, infeksi, asfiksia dan trauma kelahiran[1]. Di Indonesia penyebab kematian bayi paling tinggi disebabkan oleh prematurity[1]. Penyebab kematian bayi di Provinsi Sumatera Barat adalah asfiksia $(65,3 \%)$, kelainan kongenital (11,8\%), infeksi $(8,3 \%)$, diare $(6,1 \%)$, tetanus neonatorum $(1,4 \%)$, dan faktor lain-lain $(7,1 \%)[4]$.

Persalinan preterm akan meningkatkan angka kematian bayi secara signifikan. Setiap tahun diperkirakan sebanyak 15 juta bayi lahir dengan keadaan preterm, jumlah ini terus meningkat setiap tahunnya. Tingkat kejadian persalinan preterm berkisar 5\% sampai $18 \%$ dari seluruh persalinan. Berdasarkan data WHO tahun 2013, Indonesia menempati peringkat ke 5 dari 10 negara yang memiliki jumlah persalinan preterm tertinggi di dunia sebesar 675.700 kelahiran preterm [1].

Komplikasi dari persalinan preterm pada bayi merupakan penyebab utama kematian bayi. Bayi yang lahir preterm dapat meningkatkan risiko komplikasi dari tidak maturnya sistem organ dan gangguan perkembangan neurologis seperti cerebral palsy, gangguan intelektual, penglihatan atau pendengaran $[5,6,7]$.

Persalinan preterm disebabkan oleh karena banyak faktor, $50 \%$ terjadi secara spontan, yang terbagi menjadi $30 \%$ akibat ketuban pecah dini (KPD) dan sisanya 20\% dilahirkan atas indikasi ibu/janin. Banyak faktor yang dapat meningkatkan kemungkinan persalinan preterm, sebagian bersifat genetik, infeksi, nutrisi, perilaku dan lingkungan. Namun dalam banyak kasus persalinan preterm, munculnya pemicu persalinan yang dini terjadi secara subklinis $[8,9]$.

Pada tahun 2005, Casanueva menyatakan bahwa banyak faktor dari ibu yang menyebabkan terjadinya persalinan kurang bulan. Umur ibu yang muda atau terlalu tua, kemiskinan, ibu yang berperawakan pendek,kekurangan vitamin $\mathrm{C}$, faktor pekerjaan yaitu ibu yang bekerja berjalan dan berdiri lama, kondisi kerja yang berat, ibu bekerja terlalu sibuk dan kurang waktu waktu istirahat, jam kerja mingguan yang terlalu panjang[9].

Banyak teori yang meyebutkan penyebab dari persalinan preterm, yaitu faktor psiko-sosial demografi dan faktor ibu. Salah satu faktor psiko-sosial demografi tersebut adalah perilaku ibu. Perilaku ibu salah satunya adalah pekerjaan. Pekerjaan yang membutuhkan aktivitas berat, berdiri dalam jangka waktu lama, pekerjaan dalam industri mesin, atau pekerjaan yang memiliki efek samping lingkungan harus dimodifikasi [10].

Tujuan penelitian untuk mengetahui Hubungan Pekerjaan Ibu Dengan Kejadian Kehamilan Preterm Dengan Ketuban Pecah Dini.

\section{B. METODE PENELITIAN}

Penelitian ini merupakan penelitian observasional dengan menggunakan studi cross sectional study comparative. Penelitian ini dilakukan di Rumah Sakit Umum Daerah Dr. Rasidin Kota Padang dan Rumah Sakit Islam Siti Rahmah. Penelitian dilaksanakan September 2015-Juli 2016. Sampel penelitian ini adalah ibu 
bersalin pretem sebanyak 40 orang yang dipilih secara consecutive sampling, sampel dibagi menjadi 2 kelompok yaitu ibu bersalin preterm dengan ketuban pecah (KPD) dan ibu bersalin preterm tidak ketuban pecah dini (tidak KPD). Data yang diperoleh dari hasil penelitian dilakukan uji normalitas dengan uji Fisher dan dianalisis menggunakan uji $t$-test.

\section{HASIL DAN PEMBAHASAN}

Distribusi data dilakukan dengan menggunakan uji Fisher karena terdapat dua nilai expected kurang dari lima.

Tabel 1. Hubungan Pekerjaan Ibu dengan Persalinan Preterm

\begin{tabular}{|c|c|c|c|c|}
\hline \multirow{3}{*}{ Karakteristik } & \multicolumn{3}{|c|}{ Persalinan Preterm } & \multirow{3}{*}{$\begin{array}{c}\mathrm{p} \\
\text { value }\end{array}$} \\
\hline & KPD & Tidak KPD & Total & \\
\hline & $\mathrm{n}(\%)$ & $\mathrm{n}(\%)$ & $(\%)$ & \\
\hline $\begin{array}{c}\text { Tidak } \\
\text { Bekerja }\end{array}$ & $15(75)$ & $16(80)$ & $31(77,5)$ & \multirow[t]{3}{*}{1} \\
\hline Bekerja & $5(25)$ & $4(20)$ & $9(22,5)$ & \\
\hline Jumlah & $20(100)$ & $20(100)$ & $40(100)$ & \\
\hline
\end{tabular}

Distribusi pekerjaan ibu yang tidak bekerja pada penelitian ini sebanyak 15 orang $(75 \%)$ responden yang tidak bekerja mengalami persalinan preterm dengan KPD dan persalinan preterm non KPD adalah 16 orang (80\%) responden. Responden yang bekerja memiliki distribusi yang merata, ada 5 orang (25\%) responden yang mengalami persalinan preterm dengan KPD dan 4 orang (20\%) responden yang mengalami persalinan preterm dengan non KPD. Hasil uji statistik pekerjaan $(\mathrm{p}=1)$, tidak terdapat hubungan persalinan preterm antara responden tidak bekerja dengan responden yang bekerja.

Kejadian persalinan preterm lebih rendah pada ibu yang bukan bekerja dibandingkan dengan ibu bekerja yang hamil. Pekerjaan ibu dapat meningkatkan kejadian persalinan preterm baik melalui kelelahan fisik atau stress yang timbul akibat pekerjaannya. Jenis pekerjaan yang berpengaruh terhadap peningkatan kejadian prematuritas adalah pekerjaan terlama, pekerjaan fisik berat dan pekerjaan yang dapat menimbulkan stress berat seperti berhadapan dengan konsumen atau terlibat pada masalah keuangan/ kasir. Ibu hamil yang bekerja sering dianggap merepotkan diminta segera mengambil cuti agar tidak menganggu kelancaran pekerjaan[9].

Pekerjaan juga bisa menjadi penyebab stres, maka setelah permasalahan perkawinan pekerjaan menjadi penyebab stress, seperti pekerjaan yang terlalu banyak, menumpuk, pekerjaan yang tidak cocok dengan dirinya. Baik dari gaji yang tidak setarap atau pekerjaan yang tidak sesuai tingkat pendidikan dan keahliannya. Mutasi, kenaikan pangkat, pensiun, kehilangan pekerjaan dan sebagainya. Faktor kerja lembur, jam kerja > 42 jam seminggu merupakan salah satu stressor[11].

Berbagai bentuk stres kronis, seperti persepsi rasisme, stres dengan lingkungan atau masyarakat, tuna wisma, ketidak harmonisan rumah tangga menunjukkan efek terhadap persalinan prematur. Stres kerja adalah bentuk lain dari stres kronis. Berbagai karakteristik pekerjaan dapat sebagai stresor seperti pekerjaan mengurus rumah tangga, baik sebagai tekanan fisik maupun psikologis seperti kurangnya kontrol dan kelebihan beban pekerjaan[11].

Aktivitas fisik juga mempengaruhi kebutuhan nutrisi wanita hamil. Apabila wanita tidak dalam kondisi sehat, aktivitas yang keras dapat menyebabkan pengalihan glukosa dari janin dan plasenta ke otot-otot ibu untuk pembentukan energi. Ini juga dapat menyebabkan hipoksia janin karena aliran darah melalui plasenta dialihkan ke ibu, sehingga suplai oksigen berkurang[12].

Wanita hamil tetap dapat bekerja namun aktivitas yang dijalaninya tidak boleh terlalu berat. Istirahat untuk wanita hamil dianjurkan sesering mungkin. Seorang wanita hamil disarankan untuk menghentikan aktivitasnya apabila mereka merasakan gangguan dalam kehamilan[12].

Stress dalam jangka panjang seperti: hidup dalam kemiskinan, hubungan interpersonal yang buruk beban pekerjaan yang meningkat berkontribusi terhadap distres psikologik dan penyakit fisik. Dalam sebuah studi komunitas 
awal yang dilakukan L. L. Pearlin dan C. Schooler, terhadap 2.300 orang menemukan bahwa orang yang dilaporkan stres kronik dalam pernikahan, peran sebagai orang tua dalam rumah tangga, beban pekerjaan secara psikologis kemungkinan mengalami tekanan emosional.

Stress selama bekerja dapat memberikan rangsangan eksternal atau internal yang memunculkan gangguan pada keseimbangan hidup individu. Stress secara sederhana dapat didefinisikan sebagai suatu keadaan dimana individu dituntut untuk beradaptasi adaptif[9].

Stress akan menyebabkan pola respon individu yang dapat menyebabkan gangguan keseimbangan. Stress ditampilkan antara lain dengan meningkatkan kegelisahan, kecemasan, ketegangan, sakit kepala, tegang otot, gangguan tidur, meningkatnya tekanan darah, cepat marah, kelelahan fisik atau perubahan nafsu makan[9].

Stress pada ibu dapat meningkatkan kadar katekolamin dan kortisol yang akan mengaktifkan plasental corticotrophin releasing hormone dan mempresipitasi persalinan melalui jalur biologis. Kadar katekolamin yang tinggi dapat menyebabkan penurunan aliran darah ke janin sehingga janin kekurangan oksigen dan nutrisi[9].

Banyak penelitian menyebutkan bahwa terdapat hubungan antara stres ibu dengan kejadian persalinan preterm. Ditemukan hubungan stres psikologis ibu dengan sumbu endokrin adrenal plasenta yang diduga sebagai mekanisme dari berlangsungnya persalinan preterm $[9,10]$.

Selain itu stress juga dapat menganggu fungsi imunitas yang dapat menyebabkan reaksi inflamasi atau infeksi intraamnion dan akhirnya merangsang proses persalinan[9].

Inflamasi memicu kontraksi miometrium akibat adanya withdrawal progesteron, hal ini menyebabkan sumbu adrenal janin menjadi lebih sensitif terhadap hormon adrenokortikotropik (CRH) yang berasal dari plasenta sehingga meningkatkan sekresi kortisol. Keadaan ini meningkatkan estrogen ibu, terutama estriol. Tingginya kadar $\mathrm{CRH}$ dapat memodulasi kontraksi miometrium melalui interaksi dengan isoform reseptor $\mathrm{CRH}$ yaitu CRH-R1d yang meningkatkan kontraktil miometrium. Peningkatan kortisol dapat merangsang sintesis prostaglandin yang mempengaruhi kontraktilitas myometrium[9].

Invasi bakteri dari ruang choriodecidual menyababkan pelepasan endotoksin dan eksotoksin, dengan mengaktifkan desidua dan selaput janin untuk menghasilkan sejumlah sitokin, termasuk tumor necrosis faktor (TNF), interleukin-1, interleukin-6, interleukin-8, dan granulosit colony-stimulating factor. Selanjutnya, sitokin, endotoksin dan eksotosin merangsang sintesis prostaglandin dan melepaskan neutrofil sehingga mensintesis dan melepaskan metalloprotease dan zat bioaktif lainnya. Prostaglandin merangsang kontraksi uterus, sedangkan metalloprotease menyerang membran amnion, menyebabkan pecahnya membran amnion. Hal ini dapat menyebabkan terjadinya persalinan preterm [13].

Dalam keadaan infeksi, dehydrogenases prostaglandin (PGD2) menjadi menurun, sehingga berdampak pada peningkatan jumlah prostaglandin hal ini menyebabkan kontraksi. Jalur lain yang dapat menyebabkan persalinan preterm, dengan melibatkan janin dalam mekanisme ini. Pada keadaan infeksi, plasenta memproduksi corticotropin-releasing sehingga mempengaruhi hipotalamus janin yang menyebabkan peningkatan sekresi kortikotropin janin untuk meningkatkan sekresi kortisol janin. Peningkatan hasil sekresi kortisol oleh janin juga mempengaruhi dari peningkatan produksi prostaglandin[13].

Infeksi intraamnion seringkali bersifat kronis dan biasanya tanpa gejala sampai mulai terjadi persalinan atau PPROM. Selama proses persalinan, sebagian besar wanita yang kemudian terbukti mengalami korioamnionitis (berdasarkan bukti histologis atau kultur) tetap tidak menunjukkan gejala selain kontraksi preterm, tidak ada demam, nyeri perut atau leukositosis pada darah tepi dan biasanya tidak didapatkan takikardia janin. Infeksi intrauterin 
sering tidak bergejala maka untuk mengidentifikasinya merupakan tantangan yang besar[9].

Hasil uji statistik t-test tidak berpasangan diperoleh kesimpulan pekerjaan $(\mathrm{p}=1)$, tidak ada hubungan bermakna pekerjaan antara persalinan preterm KPD dan tidak KPD. Penelitian ini menunjukkan perbedaan antara teori dan juga hasil dari penelitian.

Berdasarkan teori dan beberapa penelitian terbukti memiliki hubungan yang signifikan antara pekerjaan dengan persalinan preterm. Faktor pekerjaan seperti berjalan atau berdiri lama, kondisi kerja yang berat dan kerja mingguan yang terlalu panjang dan padat, berdampak pada persalinan preterm. Selain itu jenis pekerjaan seperti pekerjaan terlama, pekerjaan fisik berat dan pekerjaan yang dapat menimbulkan stress berat seperti berhadapan dengan konsumen atau terlibat pada masalah keuangan/ kasir. Pekerjaan yang membutuhkan tenaga wanita yang berlebih dapat meningkatkan $20 \%-60 \%$ risiko persalinan preterm $[9,10]$.

Namun pada penelitian lain didapatkan hasil yang sebaliknya yaitu pekerjaan dan persalinan preterm tidak terbukti secara signifikan. Hasil penelitian ini sama dengan penelitian yang dilakukan oleh Karat C, et al. di India Selatan pada pretem KPD, dimana ibu yang bekerja sebagai guru dan ahli mesin masing-masing 7 orang $(4,7 \%)$ dan $1(0,6 \%)$ berada pada kelompok kontrol. Sedangkan ibu yang tidak bekerja pada kelompok kontrol sebesar 142 orang $(94,7 \%)$ dan kelompok kasus sebesar 150 (100\%)[14]. Cunningham F.G, et al memaparkan bahwa kelelahan di tempat kerja yang dilihat dari jumlah jam selama berdiri, intensitas tuntutan fisik dan mental dan stressor lingkungan, berkaitan dengan peningkatan risiko ketuban pecah dini pada preterm [9]. Walaupun demikian ibu yang tidak bekerja juga melakukan pekerjaan yang hampir sama dengan ibu bekerja.

Hal ini menunjukkan, penelitian sama menggunakan besar sampel yang besar, menunjukkan bahwa tidak terdapat hubungan antara pekerjaan dengan persalinan preterm.
Hal lain juga dapat mempengaruhi hasil dari penelitian ini yaitu jenis pekerjaan seperti pekerjaan terlama, pekerjaan fisik berat dan pekerjaan yang dapat menimbulkan stress berat, tidak terkaji. Karena dalam penelitian ini hanya melihat adanya kerja atau tidak bekerja saja dalam mengetahui penyebab dari persalinan preterm.

\section{KESIMPULAN}

Pekerjaan ibu pada ibu bersalin preterm dengan tidak ketuban pecah dini dan yang ketuban pecah dini berdasarkan uji statistic tidak ada hubungan yang signifikan $(\mathrm{p}=1)$. Distribusi pekerjaan ibu yang tidak bekerja pada penelitian ini sebanyak 15 orang (75\%) responden yang tidak bekerja mengalami persalinan preterm dengan KPD dan persalinan preterm non KPD adalah 16 orang $(80 \%)$ responden. Responden yang bekerja memiliki distribusi yang merata, ada 5 orang $(25 \%)$ responden yang mengalami persalinan preterm dengan KPD dan 4 orang (20\%) responden yang mengalami persalinan preterm dengan non KPD.

Hasil uji statistik $t$-test tidak berpasangan diperoleh kesimpulan pekerjaan $(\mathrm{p}=1)$, tidak ada hubungan bermakna pekerjaan antara persalinan preterm KPD dan tidak KPD. Penelitian ini menunjukkan perbedaan antara teori dan juga hasil dari penelitian.

Hal ini dapat terjadi disebabkan oleh penelitian sama menggunakan besar sampel yang besar, menunjukkan bahwa tidak terdapat hubungan antara pekerjaan dengan persalinan preterm.

Hal lain juga dapat mempengaruhi hasil dari penelitian ini yaitu jenis pekerjaan seperti pekerjaan terlama, pekerjaan fisik berat dan pekerjaan yang dapat menimbulkan stress berat, tidak terkaji. Karena dalam penelitian ini hanya melihat adanya kerja atau tidak bekerja saja dalam mengetahui penyebab dari persalinan preterm. 


\section{DAFTAR PUSTAKA}

[1]. World Health Organization (WHO). Preterm Birth. WHO [Update Number] 2015 November (diunduh 3 Oktober 2015). Tersedia dari: URL: HYPERLINK http://www.who.int/mediacentre/factsheet s/fs363/en/.

[2]. World Bank Group. 2014. "Mortality Rate, Infant (per 1,000 live births)". http://data.worldbank.org/indicator/SP.D

YN. IMRT.IN. Diakses pada Sabtu, 3 Oktober 2015, jam 17.00.

[3]. Badan Pusat Statistik (BPS). "Survei Demografi dan Kesehatan Indonesia (SDKI) tahun 2012”. BPS [Update Number] 2015 Juni (diunduh 17 Oktober 2015). Tersedia dari: URL: HYPERLINK https://www.bps.go.id/

[4]. Dinas Kesehatan Kota Padang. (2015). Profil Kesehatan Kota Padang tahun 2014. DINKES Kota Padang, Padang.

[5]. Norman, J and Greer, I. (2016). Preterm Labour: Managing Risk in Clinical Practice. $N$ Engl J Med., 35, 669-674.

[6]. Manuaba IBG, Manuaba IAC \& Manuaba IGF. (2007). Pengantar Kuliah Obstetri. EGC, Jakarta.

[7]. Romero R, Dey S and Fisher SJ. (2014). Preterm Labor: One Syndrome, Many Causes. National Institutes of Health., 345, 760-765.

[8]. Prawirohardjo, Sarwono (2008), Ilmu Kebidanan. Bina Pustaka Sarwono Prawirohardjo, Jakarta.

[9]. Cunningham FG, Leveno K, Bloom S, Spong CY, \& Dashe J. (2014). Williams Obstetrics 24rd. McGraw-Hill Education, New York

[10]. Blencowe, H, Cousens, S, Chou, D, Oestergaard, M, Say, L, Moller, A.B,. et al.(2013). Review: Born Too Soon: The Global Epidemiology of 15 Million Preterm Births. London: Reproductive Health., 10, 10-24.

[11]. Contrada J.R, (2011). The Handbook of Stress Science. Biology, Psychology, and Health. Printed in the United States of America by Bang Printing, 24. 321337.Bobak dkk. (2005). Buku Ajar Keperawatan Maternitas Edisi 4. EGC. Jakarta.
[12]. Prasmusinto, D, Aminullah, A, Sungkar, A, Sitepu, M, Ilhamy., et al. (2010). Prediksi Persalinan Preterm. Konvensi Health Technology Assessment Indonesia. Indonesia.

[13]. Karat C, Madhivanan P, Krupp K, Poornima S, Jayanthi NV, Suguna JS., et al. (2006). The Clinical And Microbiological Correlates of Premature Rupture of Membranes. Indian Journal of medical Microbiology., 24, 283-285. 